\section{The correlation between hemostatic parameters and mortality rate in patients with non-small cell lung cancer}

\author{
Noni Novisari Soeroso, ${ }^{1}$ Fannie Rizki \\ Ananda, ${ }^{1}$ Ganda Samosir, ${ }^{1}$ Herman \\ Hariman, ${ }^{2}$ Putri Chairani Eyanoer ${ }^{3}$ \\ ${ }^{1}$ Department of Pulmonology and \\ Respiratory Medicine, Faculty of \\ Medicine Universitas Sumatera Utara, \\ Universitas Sumatera Utara Hospital; \\ ${ }^{2}$ Department of Clinical Pathology, \\ Faculty of Medicine Universitas \\ Sumatera Utara, Adam Malik General \\ Hospital; ${ }^{3}$ Department of Community \\ Medicine, Faculty of Medicine \\ Universitas Sumatera Utara, Indonesia
}

\section{Abstract}

The increasing level of hemostatic parameters and tumor markers were associated with cancer progression and poor prognosis, particularly in NSCLC. The objective of this study is to determine whether there was a correlation between hemostatic parameters and mortality rate in patients with NSCLC. This was a prospective analytical study with a pretest-posttest design which included 41 patients with diagnosis of NSCLC. Plasma levels of PT, APTT, TT, $\mathrm{D}$-dimer, and fibrinogen were measured before initiation of chemotherapy and remeasured after 4 cycles or 6 cycles of chemotherapy, based on the clinical condition of patients. Then, patients were followed up for 1 year to evaluate the mortality rate. The majority of subjects were male $(85.4 \%)$ with adenocarcinoma (75.6\%). There was no significant difference in mean between adenocarcinoma and squamous cell carcinoma $(\mathrm{P}>0.05)$. Most patients died after one month of follow up (61\%). The parameters which could predict high mortality rate in NSCLC were prolonged PT and the increased of D-dimer with $\mathrm{RR}>1$, although they had not significant in statistical analysis $(\mathrm{P}>0.05)$. There is no correlation between hemostatic parameters and mortality rate in patients with NSCLC.

\section{Introduction}

Nowadays, there are many studies which concern on hemostatic parameters on cancer. A number of studies showed a correlation between hemostatic parameters on cancer progression in line with poor prognosis. ${ }^{1-3}$ The increased of D-dimer, fibrinogen, thrombocytosis can be used as independent prognostic parameters of lung cancer, as well as other solid tumors such as pancreatic, gastric, breast, and colorectal cancer. ${ }^{1-8}$ Tumor cells and or tumor-associated inflammatory cells can induce clotting and fibrinolytic system. ${ }^{4,9}$ These hypercoagulable state also act as the growth factor for tumor itself and facilitates tumor angiogenesis. Fibrin deposition in cancer tissue can againts inflammatory cells which destroy the tumor cells. Further, plasmin activator contributes to tumor invasion into blood circulation. ${ }^{10} \mathrm{D}$-dimer as a product of plasmin degradation serves as a sensitive marker of fibrinolytic process. Its role has been investigated in tumor burden, clinical progression, response of therapy and had a strong association with poor prognosis of lung cancer. ${ }^{9,11,12}$

The objective of this study is to determine whether there was a correlation between hemostatic parameters and mortality rate in patients with NSCLC.

\section{Materials and Methods}

This was a prospective analytical study with one group posttest-pretest design that held in Department of Pulmonology and Respiratory Medicine, Faculty of Medicine, Universitas Sumatera Utara for 17 months in 2015-2016. This study protocol was approved by the Ethics Committee of Faculty of Medicine in Universitas Sumatera Utara.

\section{Patients}

This study included 41 participants with non-small cell lung cancer. Diagnosis was made by history taking, physical examination, and work-up examinations such as chest X-Ray, chest computed-tomography with contrast, and then confirmed by biopsy and cytology taken at bronchoscopy. Patients who had coagulation disorder, in taking anti-coagulant medications, or had other malignancies beside lung cancer were excluded. Smoking history was based on medical records and categorized as active smoker and non-smoker. Active smoker was patients who had consumed $\geq 100$ cigarettes per years. Before taking chemotherapy, all participants got an initial examination such as performance status by WHO classifications, liver function test, renal function test, and hemostatic parameters. These tests were examined 7 days before chemotherapy procedure. One cycle of chemotherapy lasted 21 days. Then, second examinations
Correspondence: Noni Novisari Soeroso, Department of Pulmonology and Respiratory Medicine, Faculty of Medicine, Universitas Sumatera Utara, Dodik Road No. 11, Medan Helvetia, North Sumatera 20126, Indonesia. Tel.: 08126018608.

E-mail: noni@usu.ac.id

Key words: Hemostatic parameters, Mortality rate, Non-Small Cell Lung Cancer, Chemotherapy.

Acknowledgments: The authors would like to thank Haji Adam Malik Hospital Medan, Indonesia for the opportunity and place provided for conducting this research.

Contributions: The authors contributed equally.

Conflict of interest: The authors declare no potential conflict of interest.

Funding: None.

Ethics approval: This study has been approved by Ethics Committee of Faculty of Medicine Sumatera Utara 2017 according to Declaration of Helsinki.

Availability of data and materials: This study has not any supplementary materials. All data and materials are available within the text.

Received for publication: 31 October 2019. Accepted for publication: 10 July 2020 .

This work is licensed under a Creative Commons Attribution-NonCommercial 4.0 International License (CC BY-NC 4.0).

(C) Copyright: the Author(s), 2021

Licensee PAGEPress, Italy

Hematology Reports 2021; 13:8361

doi:10.4081/hr.2021.8361

were done after fourth cycle of chemotherapy (4th month) and after the end of first-line chemotherapy (6th month).

\section{Blood collection}

A blood sample was obtained by peripheral venous puncture and collected in a tube containing EDTA for anti-coagulant. Prothrombin (PT), Activated Partial Thromboplastin Time (APTT), Thrombin Time (TT) were analyzed using Coatron A4 with photo optic and electromechanics. Fibrinogen was analyzed using Coatron A4 with optic LED laser. D-dimer was analyzed using Coatron A4 with immunoturbidimetric assay.

\section{Statistical analysis}

All these data were analyzed using Epi 
Info $^{\mathrm{TM}} 7$ programs. The results of PT, APTT, D-dimer, and fibrinogen were reported as mean \pm standard deviation (SD). Normality test was done using One-Sample Kolmogorov-Smirnov Test. Mann Whitney test was done to know whether there was a significant difference of hemostatic parameters in Lung Adenocarcinoma and squamous cell lung cancer (SCC), pre and post chemotherapy, and after 1-year survival. Logistic regression was done to know which parameters of hemostatic that contribute to prognostic of NSCLC. $\mathrm{P}<0.05$ considered to be significant.

\section{Results}

Total of 41 participants included in this study age $\geq 40$ years old with the diagnosis of NSCLC. From Table 1, we can see that the majority of the subject is male, smoker, in 50-59 age groups with type of cancer was adenocarcinoma. Most patients have received gemcitabine as drug of choice of their chemotherapy. General characteristics of this study can be seen in Table 1 .

In this study, there were two groups of patients based on histopathology of NSCLC. They were squamous cell carcinoma and adenocarcinoma. Mann Whitney test found that there were no significant differences among hemostatic parameters in both groups with $\mathrm{P}>0.05$. Mean of each parameter can be seen in Table 2. After assessed the baseline data of all participants, we did a 1-year follow up. The highest rate of mortality was occurred one month after diagnosis of NSCLC. From this study, we see that more than $60 \%$ percent of participants was death after one month. And when the follow up was continuing, we could see that only $12 \%$ of NSCLC who could survive after 1-year (Table 3).

After 1 month and 1 year follow up, hemostatic parameters were assessed in participants who survived. Hemostatic parameters and tumor marker were categorized as normal and abnormal. The cutting of points on abnormal level were PT $>14 \mathrm{~s}$, APTT $>30$ s, TT>14 s, D-dimer $>375$ ug/l, CEA $>5$ IU, NSE $>17$ IU, Cyfra $>10$ IU. From Table 4 we could see the parameters which could predict poor prognosis in NSCLC were prolonged PT, the increased of D-dimer, and CEA with $R R>1$, although they had not significant in statistical method using logistic regression $(\mathrm{P}>0.05)$. The increase of NSE ( $>17$ IU) was significant to predict 1-year survival rate of patients with NSCLC.

\section{Discussion}

Lung cancer is one of the common malignancy in both women and men which has a poor prognosis. ${ }^{13}$ These made many studies concern on searching for predictors on survival rate of lung cancer, such as tumor staging, genetic factors, tumor markers, inflammatory markers, and hemostatic parameters (14). In lung cancer, these prognostic factors are useful in understanding the course of disease, choosing alternative treatment, and educating the patients. ${ }^{4}$

Recent years, a number of studies have revealed basic hemostatic parameters such as platelet, PT, APTT, D-dimer, AT-III increased in lung cancer. ${ }^{4,5,10}$ Almost 90\% advanced stage cancer has coagulation factor abnormalities, including prolonged and

Table 1. General characterics of participants.

\begin{tabular}{|c|c|c|}
\hline Characteristics & $\mathbf{N}$ & $\%$ \\
\hline $\begin{array}{l}\text { Age } \\
\qquad \begin{array}{l}40-49 \\
50-59 \\
>=60\end{array}\end{array}$ & $\begin{array}{c}7 \\
20 \\
14\end{array}$ & $\begin{array}{l}17.1 \\
48.8 \\
34.1\end{array}$ \\
\hline $\begin{array}{l}\text { Sex } \\
\quad \text { Male } \\
\text { Female }\end{array}$ & $\begin{array}{c}35 \\
6\end{array}$ & $\begin{array}{l}85.4 \\
14.6\end{array}$ \\
\hline $\begin{array}{l}\text { Histopathology } \\
\text { quamous cell ca } \\
\text { Adenocarcinoma }\end{array}$ & $\begin{array}{l}10 \\
31\end{array}$ & $\begin{array}{l}24.4 \\
75.6\end{array}$ \\
\hline $\begin{array}{l}\text { Stage } \\
\text { I-IIB } \\
\text { IIIa-IIIb } \\
\text { IV }\end{array}$ & $\begin{array}{c}3 \\
15 \\
23\end{array}$ & $\begin{array}{c}7,3 \\
36.6 \\
56.1\end{array}$ \\
\hline $\begin{array}{l}\text { Smoking history } \\
\text { Smoker } \\
\text { Nonsmoker }\end{array}$ & $\begin{array}{c}35 \\
6\end{array}$ & $\begin{array}{l}85.4 \\
14.6\end{array}$ \\
\hline $\begin{array}{l}\text { History of chemoterapy } \\
\text { Paclitacsel } \\
\text { Gemcitabine } \\
\text { Vinorelbine }\end{array}$ & $\begin{array}{c}10 \\
27 \\
4\end{array}$ & $\begin{array}{c}24.4 \\
65.9 \\
9.8\end{array}$ \\
\hline $\begin{array}{l}\text { One month follow up post chemotherapy } \\
\text { None } \\
\text { Motoric disabily } \\
\text { Death }\end{array}$ & $\begin{array}{c}2 \\
14 \\
25\end{array}$ & $\begin{array}{r}4.9 \\
34.1 \\
61.0\end{array}$ \\
\hline $\begin{array}{l}\text { One year follow up post chemotherapy } \\
\text { None } \\
\text { Motoric disabily } \\
\text { Death } \\
\text { Total }\end{array}$ & $\begin{array}{c}2 \\
3 \\
36 \\
41\end{array}$ & $\begin{array}{r}4.9 \\
7.3 \\
87.8 \\
100\end{array}$ \\
\hline
\end{tabular}

Table 2. Baseline mean and SD of hemostatic parameters and tumor markers of different type of NSCLC.

\begin{tabular}{|c|c|c|c|c|c|c|}
\hline \multirow{2}{*}{\multicolumn{2}{|c|}{ Reference level }} & \multicolumn{2}{|c|}{ Adenocarcinoma (n=31) } & \multicolumn{2}{|c|}{ Squamous Cell $\mathrm{Ca}(\mathrm{n}=10)$} & \multirow[t]{2}{*}{ P leve } \\
\hline & & Mean & SD & Mean & SD & \\
\hline PT & $10-14 \mathrm{~s}$ & 13.3 & 1.16 & 13.5 & 1.87 & 0.68 \\
\hline APTT & $25-30 \mathrm{~s}$ & 30.3 & 3.44 & 30.2 & 2.21 & 0.95 \\
\hline TT & $10-14 \mathrm{~s}$ & 14.3 & 1.67 & 15.1 & 3.38 & 0.504 \\
\hline INR & $1.0-2.0$ & 0.96 & 0.09 & 0.97 & 0.14 & 0.65 \\
\hline D-Dimer & $<375 \mathrm{ug} / \mathrm{l}$ & 802.1 & 627.8 & 644.3 & 366.8 & 0.58 \\
\hline
\end{tabular}

Mann Whitney Test. 
Table 3. One year follow up of NSCLC.

\begin{tabular}{lcc} 
Survival rate & N. & $\%$ \\
Baseline & 41 & 100 \\
1 month follow up & 16 & 39.0 \\
\hline 1 -year survival & 5 & 12.2 \\
\hline
\end{tabular}

Table 4. Prognostic role of hemostatic parameters and tumor marker.

\begin{tabular}{lcccc} 
& \multicolumn{2}{c}{ RR } & \multicolumn{2}{c}{ 1-year survival } \\
& & P-level & RR & P-level \\
PT $>14 \mathrm{~s}$ & 2.03 & 0.35 & 1.53 & 0.71 \\
$\mathrm{aPTT}>30 \mathrm{~s}$ & 0.99 & 0.98 & 0.83 & 0.85 \\
\hline $\mathrm{TT}>14 \mathrm{~s}$ & 0.71 & 0.61 & 5.01 & 0.18 \\
$\mathrm{INR}<1.0$ & 0.35 & 0.63 & 0.35 & 0.63 \\
\hline D dimer $>375$ & 1.06 & 0.92 & 1.17 & 0.86 \\
\hline
\end{tabular}

*P level considered significant in logistic regression.

shortened PT and APTT, increased and decreased intrinsic or extrinsic coagulation factors, increased fibrinogen and other fibrin degradation products such as D-dimer, and simple predictors such as increase of platelet count. 4,14

Lung cancer was divided into 2 groups based on type of cell, NSCLC, and SCLC. These groups have different mechanisms for activating coagulation cascade. In SCLC, tumor cells directly activating coagulation cascade by releasing tissue factor. In the other hand, NSCLC activates coagulation cascade by host macrophage system. ${ }^{10}$ Based on histopathology, NSCLC was divided into adenocarcinoma, squamous cell carcinoma, large cell carcinoma (undifferentiated), and other subtypes such as adenosquamous carcinoma, etc. In this study, we can see that the majority of subject had adenocarcinoma (Table 1). This is in line with Soeroso et al that found the most common NSCLC was adenocarcinoma $(80.9 \%) .{ }^{15}$

Along with the course of disease, chemotherapy also increases hypercoagulable state risk, depending on duration and particular agents. Platinum-based chemotherapy, anthracyclines, and nitrogen mustard analogs have an association with venous thromboembolism (VTE) state in various solid tumor malignancy. ${ }^{16,17}$ Ruiz et al. and Ferigno et al. showed increasing hemostatic parameters after chemotherapy in various solid cancer. ${ }^{4,18}$ Chemotherapy can increase the risk of VTE until 6-8 fold higher than without chemotherapy. ${ }^{18}$ The mechanism of thromboembolic event after chemotherapy was poorly understood. One of the hypotheses that explains this phenomena is chemotherapy, particularly cisplatin-based therapy can directly induce endothelial damage and increase tissue fac- tor procoagulant activity of macrophages. ${ }^{19}$ Other factors contributing this are cytokine release by apoptosis of tumor and endothelial cells that later increase tissue factors which enhance hypercoagulable state. ${ }^{20}$

The site of cancer is one of the risk factors of VTE in malignancy. Whereas, the highest incidence of VTE is associated with pancreatic tumor, lung, GI tract, and brain tumor. $^{21,22}$ Another factor is histology of cancer that showed a higher risk of VTE in adenocarcinoma rather than squamous cell carcinoma in NSCLC. ${ }^{16,23}$ But in this study, there were no significant differences in hemostatic parameters between adenocarcinoma and squamous cell carcinoma lung cancer (Table 2). This is in line with Unsal study that showed there was no significant differences in PLT, PT, APTT, fibrinogen, AT-III, and fibrinogen among histology of lung cancer. ${ }^{10}$

Hemostatic parameters as prognostic indicators of NSCLC remain controversial. Many studies showed a strong correlation between hemostatic parameters and cancer progression in line with poor prognosis. ${ }^{1-3}$ In this study, we found that prolonged PT and the increasing level of D-dimer had increased mortality rate although it was not significantly correlated in statistical analysis. Buccheri study showed PT was a significant prognostic predictor in lung cancer. ${ }^{24}$ In contrast, Unsal study found there was no significant correlation between PT and survival rate of lung cancer. ${ }^{10}$

D-dimer is a product of fibrin degradation and reflects the severity of fibrinolytic process. ${ }^{10}$ The increased level of D-dimer associated with progressivity of lung cancer and poor prognosis of lung cancer. This is in line with Wang study, Kadlec study, and Unsal study that found a significant correlation between D-dimer and poor prognosis of lung cancer, particularly NSCLC. ${ }^{10,25,26}$

Other hemostatic parameters were APTT, TT, and INR. In this study, we found that APTT was higher in NCLC patients but did not correlate significantly with poor prognosis of NSCLC. This is in line with Tas study and Unsal study that showed an increased level of APTT in lung cancer, but not significantly correlated in statistical analysis. ${ }^{10,27}$ In this study, we found an increase in TT and INR in NSCLC patients but they were not significantly correlated. This is in contrast with Tas study that found a significant correlation between TT and INR with poor prognosis and short survival in lung cancer. ${ }^{27}$

\section{Conclusions}

There is no correlation between hemostatic parameters and mortality rate in patients with NSCLC.

\section{References}

1. Dirix LY, Salgado R, Weytjens R, et al. Plasma fibrin D-dimer levels correlate with tumour volume, progression rate and survival in patients with metastatic breast cancer. Br J Cancer 2002;86:38995.

2. Altiay G, Ciftci A, Demir M, et al. High Plasma d-dimer Level is Associated with Decreased Survival in Patients with Lung Cancer. Clin Oncol 2007; 19:494-8.

3. Pedersen LM, Milman N. Prognostic significance of thrombocytosis in patients with primary lung cancer. Eur Respir J 1996;9:1826-30.

4. Ferrigno D, Buccheri G, Ricca I. Prognostic significance of blood coagulation tests in lung cancer. Eur Respir J [Internet]. Eur Respir Soc 2001;17:66773.

5. Buccheri G, Ferrigno D, Ginardi C, Zuliani C. Haemostatic abnormalities in lung cancer: prognostic implications. Eur J Cancer 1997;33:50-5.

6. Jones JM, McGonigle NC, McAnespie $\mathrm{M}$, et al. Plasma fibrinogen and serum C-reactive protein are associated with non-small cell lung cancer. Lung Cancer 2006;53:97-101.

7. Guo Q, Zhang B, Dong X, et al. Elevated Levels of Plasma Fibrinogen in Patients With Pancreatic Cancer. Pancreas 2009;38:e75-9.

8. Yamashita H, Kitayama J, Nagawa H. Hyperfibrinogenemia is a Useful Predictor for Lymphatic Metastasis in 
Human Gastric Cancer. Jpn J Clin Oncol 2005;35:595-600.

9. Wojtukiewicz MZ, Sierko E, Klement P, Rak J. The hemostatic system and angiogenesis in malignancy. Neoplasia 2001;3:371-84.

10. Unsal E, Atalay F, Atikcan S, Yilmaz A. Prognostic significance of hemostatic parameters in patients with lung cancer. Respir Med 2004;98:93-8.

11. Seitz R, Rappe N, Kraus M, et al. Activation of coagulation and fibrinolysis in patients with lung cancer: relation to tumour stage and prognosis. Blood Coagul Fibrinolysis 1993;4:249-54.

12. Ursavaş A, Üniversitesi Tıp Fakültesi U, et al. Prognostic Significance of Plasma D-Dimer Levels in Patients with Lung Cancer. Eur J Gen Med 2010 [cited 2019 Mar 11].

13. Kim DN, Nam TK, Choe KS, Choy H. Personalized Combined Modality Therapy for Locally Advanced Nonsmall Cell Lung Cancer. Cancer Res Treat 2012;44:74-84.

14. Zhang X, Ran Y. Prognostic role of elevated platelet count in patients with lung cancer: a systematic review and meta-analysis. Int J Clin Exp Med 2015;8:5379-87.

15. Soeroso NN, Tanjung MF, Afiani D, et al. Procalcitonin Level in Non-Small
Cell Lung Cancer Patients among Indonesian Population. Maced J Med Sci 2018;6:2123-7.

16. Blom JW, Osanto S, Rosendaal FR. The risk of a venous thrombotic event in lung cancer patients: higher risk for adenocarcinoma than squamous cell carcinoma. J Thromb Haemost 2004;2: 1760-5.

17. Kröger K, Weiland D, Ose C, et al. Risk factors for venous thromboembolic events in cancer patients. Ann Oncol 2006;17:297-303.

18. Ruiz MA, Estelles' A, Navarro I, et al. The Influence of Chemotherapy on Plasma Coagulation and Fibrinolytic Systems in Lung Cancer Patients. cited 2019 Mar 11. Available from: https://onlinelibrary.wiley.com/doi/pdf/ 10.1002/1097-0142(19890215)63:4\% 3C643::AID-CNCR2820630407\% 3E3.0.CO;2-J

19. Khorana AA, Dalal M, Lin J, Connolly GC. Incidence and predictors of venous thromboembolism (VTE) among ambulatory high-risk cancer patients undergoing chemotherapy in the United States. Cancer 2013;119:648-55.

20. Previtali E, Bucciarelli P, Passamonti SM, Martinelli I. Risk factors for venous and arterial thrombosis. Blood Transfus 2011;9:120.
21. Khorana AA, Connolly GC. Assessing risk of venous thromboembolism in the patient with cancer. J Clin Oncol 2009;27:4839-47.

22. Haddad TC, Greeno EW. Chemotherapy-induced thrombosis. Thromb Res 2006;118:555-68.

23. Chew HK, Wun T, Harvey D, et al. Incidence of Venous Thromboembolism and Its Effect on Survival Among Patients With Common Cancers. Arch Intern Med 2006;166:458.

24. Buccheri G, Ferrigno D, Ginardi C, Zuliani C. Haemostatic abnormalities in lung cancer: Prognostic implications. Eur J Cancer 1997;33:50-5.

25. Wang Y, Wang Z. Predictive value of plasma D-dimer levels in patients with advanced non-small-cell lung cancer. Onco Targets Ther 2015;8:805-8.

26. Kadlec B, Skrickova J, Merta Z, et al. The incidence and predictors of thromboembolic events in patients with lung cancer. Sci World J 2014:125706.

27. Tas F, Kilic L, Serilmez M, et al. Clinical and prognostic significance of coagulation assays in lung cancer. Respir Med 2013;107:451-7. 